\title{
Lost in Translation? Exploring Outcomes of Nunavut's Resource Development Training and Employment Policies for Inuit of Northern Baffin Island
}

\author{
Andrew Hodgkins
}

\begin{abstract}
On 6 September 2013 the Mary River Inuit Impact and Benefit Agreement (MRIIBA) was signed between the Qikiqtani Inuit Association (QIA), representing the Inuit of Baffin Island, and Baffinland Iron Mines Corporation (BIMC). Among other things, the MRIIBA is intended to promote Inuit employment and training as a way of maximizing local benefits from the mine. Drawing from qualitative research that followed twenty-two formerly-employed and employed mine workers, this article critically evaluates the agreement's outcomes, which have yet to fulfill the stated employment goals and training provisions. Contributing to these dismal outcomes is a communications gap between local Inuit and the land claims organizations responsible for brokering the agreement with the project proponent. The article explores the resulting gaps in communication between community members and various stakeholders involved with the project, and concludes by offering considerations for future agreements.
\end{abstract}

The Northern Review 47 (2018): 31-57 


\section{Introduction}

In Canada, non-renewable resource development has fostered the creation of modern-day treaties known as land claims settlements. Since 1973, Canada and its negotiation partners have signed twenty-six "comprehensive" land claims. ${ }^{1}$ Land claims settlements are intended to remove "legal uncertainty on use and disposition of land and resources" (Mitchell, 1996, p. 360) in order to attract development; concomitantly, land claims are also heralded by Indigenous groups as a foundation towards greater self-determination. Alongside these settlements have emerged what are termed impact and benefit agreements (IBAs), which are brokered between land claims organizations and industry players. The intention of IBAs is ostensibly to help ensure communities benefit from non-renewable resource development while the impacts of a project are minimized. Owing to remote Indigenous communities' heavy reliance on government welfare, IBAs receive the support from the state, and represent a policy shift towards neo-liberal ${ }^{2}$ Indigenous-industry-state private-public partnerships. A central focus of these agreements relates to their provision for vocational education and training, as well as preferential employment opportunities. In regions where resource development occurs, federal government funding agreements for training are tied to the ability of local communities to partner with resource developers (ASEP, n.d.; GoC, 2000, 2009, 2013). Communities are therefore encouraged to grant social licence for a mining development, and in return they gain much needed training and employment opportunities. At the same time, IBAs also provide land claims organizations with an independent source of capital through access to economic rents.

Our ability to ascertain actual training and employment benefits is hampered by the confidential nature of IBAs and their lack of transparency, as most agreements contain non-disclosure clauses that interfere with public understanding and participation (Caine \& Krogman, 2010). Recently, however, provisions of one agreement-the Mary River Inuit Impact Benefit Agreement (MRIIBA, 2013) negotiated between the Qikiqtaaluk Inuit Association (QIA), representing the Inuit of Baffin Island (Qikiqtaaluk) in Nunavut, and Baffinland Iron Mines Corporation (BIMC), an international iron ore company-have been made public in terms of the money that beneficiaries ${ }^{3}$ and their communities will receive from the company. ${ }^{4}$ The Mary River project (the project) is located on Inuitowned lands in the North Baffin region of Nunavut. The project is a multibillion dollar, open-pit, high-grade iron ore mine, with a life expectancy 
of twenty-one years and opportunities for expansion (Dalseg \& Abele, 2015). Over this time frame, the project is expected to generate thousands of jobs while in operation, triple the growth rate of the territory's annual gross domestic product, and provide nearly $\$ 5$ billion in tax revenue and royalties (Ritsema et al., 2015).

Based upon Article 26 of the Nunavut Land Claims Agreement (NLCA), project developers must negotiate an Inuit Impact and Benefit Agreement (IIBA) with regional Inuit organizations (RIAs), and offer compensation, royalties, local employment and training, and business contracts. ${ }^{5}$ The MRIIBA is supposed to ensure that the five signatory communities in the Qikiqtaaluk region specifically benefit from the mine through royalties, priority-hiring arrangements, and education and training programs including trades apprenticeships. A minimum-Inuit-employment goal of 25\% for Baffinland staff and for all new contracts awarded in 2016 has also been identified, although only half that rate has been achieved (Bell, 2017; Brown, 2017). To achieve the goal, Article 8.1.6 of the agreement requires that various stakeholders-including the company, the Inuit association QIA, territorial training institutions, and the different North Baffin communities - "use their best efforts ... to promote communication [my emphasis] among education and training participants" (MRIIBA, 2013, p. 67).

This article digs beneath Nunavut's skills shortage by sharing findings from a longitudinal empirical case study that involved various stakeholders, as well as mine employees and former employees ("workers") in the hamlet of Mitmattilik (Pond Inlet)-which is one of the five locally affected communities. As context, I begin by presenting an historical overview of Inuit labour participation in Nunavut's mining industry, and its intersection with the political economy of land claims that continues to privilege IBAs as the means to broker training and employment opportunities. I then provide the methodology and findings based upon interviews and field work conducted during the summers of 2015 and 2016. Findings reveal significant areas of miscommunication between workers and various stakeholders, which undermines attempts to develop a skilled workforce for the project. The research is conceptually located within critiques concerning the neo-liberal imposition of IBAs as a policy tool to broker training and employment opportunities for Indigenous Canadians (e.g., Caine \& Krogman, 2010; Cameron \& Levitan, 2014; Kulchyski \& Bernauer, 2014; see also Taylor \& Friedel, 2011). The analysis is also informed by conjectures that regional class divisions are 
contributing to mistrust and miscommunication between community members and land claims organizations.

\section{Inuit Training and Employment in the Resource Extractive Industries}

Despite a recent history of affirmative action hiring policies in both the public and private sectors, Nunavut's social and economic development is undermined by a low labour force participation rate by Inuit. As Thomas Berger (2006) lamented, "Under Article 23 [of the Nunavut Land Claims Agreement] the Inuit ought to have $85 \%$ of the positions in the public service. The fact is, however, that only $45 \%$ of the employees of the Government of Nunavut are Inuit" (p. 7). Similar challenges are also experienced in the mining sector. The Conference Board of Canada (CBC, 2017) reports that economic growth in Nunavut is forecasted to increase by $6.5 \%$ in the coming years owing to new mining developments, yet economic development is stymied by Nunavut's labour force, which lacks necessary skills to sustain the territory's mining operations, forcing employers to rely heavily on fly in, fly out workers to supplement the local supply of labour (p. 13). ${ }^{6}$ Inuit participation in this sector is characterized as short term, low skilled, and with exceptionally high turnover rates especially after the construction phase of a project is completed. The highest proportion of Inuit employees reported, 34\%, is at the Meadowbank gold mine (Mining Journal, 2015, cited in Palesch, 2016, p. 30). However, it is also noted that prior to this there was an $80 \%$ turnover in Inuit labour; of the 276 Inuit workers hired in 2011, 229 departed (Bell, 2012). At the Mary River project, Inuit employment has continually declined from $20.3 \%$ of the total $(n=800)$ workers in 2014, to $16.7 \%$ between January and June 2016, to $12.5 \%$ in 2017 (Bell, 2017). Similar figures are also reported in other Inuit communities, as noted at Nunavik's Raglan nickel mine in northern Quebec where Inuit make up 19\% of the workforce (Glencoe, 2015, cited in Palesch, 2016, p. 31). In each of these cases, employment outcomes are much lower than those initially identified in IIBAs.

Historically, training, employment, and retention of an Inuit labour force has always been challenging. Beginning in 1957, when the first modern mine in Nunavut opened near Rankin Inlet, the six-year underground nickel mine employed eighty Inuit full-time and around twenty others part-time in 1961 (Rodon \& Levesque, 2015). The Nanisivik lead-zinc mine, which began construction in 1974 and operated near the Baffin Island community of Arctic Bay from 1976 to 2002, also employed relatively few Inuit, with most working no more than one or two months despite reporting that they liked their work and the money they earned (Hobart, 1982, p. 60); the proportion of workers quitting before completing 
a six-week work period generally increased from $11 \%$ in 1975 , to $22 \%$ in 1976, 30\% in 1977, and 23\% in 1978 (p. 60). And of those Inuit employed, only $5 \%$ were apprentices, $23 \%$ were semi-skilled workers, and $8 \%$ were heavy equipment operators, with the remainder engaged as labourers (43\%) and helpers (16\%) (p. 62).

Reasons for low participation rates usually involve a combination of factors, and follow a similar pattern. Hobart (1982) noted three distinctive characteristics of the Inuit workforce that contributed to high turnover rates: the very wide area from which they were recruited; their relative youth (median age was 28); and the high proportion that were singlecharacteristics he attributed to the relative disinterest of many Inuit ( $\mathrm{p}$. 58). Rodon and Levesque (2015) also speculate as to how the evolution of mining has impacted employment in recent years:

in the 1950s one could not easily "fly-in and fly-out" the miners needed. Now, however, this practice has become the norm for northern mines, and local workers are no longer so necessary. In addition, the mining profession has changed a lot over the years. Mines have gone from primarily manual jobs that required little education and much physical ability, to skilled trades that require higher education and proficiency in complex technologies. (p. 32)

The authors also note that Inuit have not always been interested in the jobs made available to them and would rather study in fields of their own choice, and when work is made available there is little opportunity to gain promotions (p. 26). Other reasons for the low participation rate include the nature of shift work, which requires workers to be away from their families for two weeks at a time; conflicts between shift work and spring hunting; and the overly complex system for processing job applications (Bell, 2017).

Nunavummiut are also plagued by a host of interrelated and mutually reinforcing social problems that preclude wage labour participation. As Hicks and White (2015) explain:

Overcrowded, substandard housing contributes to family violence, to serious health problems, and to poor educational achievement; unemployment reflects low standards of training and education, perpetuating poverty and welfare dependency, in turn stymying efforts to escape bad housing. The extensive linkages between social ills renders them all the more difficult to combat. (p. 40) 
Other social indicators cited by the authors include rampant sexual and child abuse, the lowest high school graduation rate in the country, and a suicide rate almost forty times higher than the national average (p. 41).

\section{Neo-Liberalization of Training and Employment Policies}

Given the fact that Inuit participation in resource extractive industries continues to remain low, one may well question the impact (if any) that the settlement of the Nunavut Land Claims Agreement in 1993 has had on improving employment opportunities for Inuit. ${ }^{7}$ To understand why Nunavummiut employment has not fared any better since the creation of Nunavut in 1999, we need to consider the region's governance challenges that have impacted communication between community members, the various levels of governance responsible for their interests, and industry players, and that have contributed to the ad hoc and fragmented approach to training and employment programs that currently exists.

Geopolitically, the territory encompasses one-fifth of Canada's land mass and is inhabited by a sparse population of approximately 38,243 people (GN, 2017) $-85 \%$ of whom are Inuit. In response to the low population density, the territorial government has opted to decentralize local governance into three regions - the Kitikmeot, Kivalliq, and Qikiqtaaluk. Despite lacking autonomous governments of their own, these regions form the basis for more localized administration intended to provide a measure of self-determination over their respective regional political and economic affairs, as well as "deconcentrate" government jobs (and associated infrastructure) away from the capital of Iqaluit to regional communities (Hicks \& White, 2015).

Three levels of government-federal, territorial, and municipal-are responsible for administering services to Inuit. The bulk of Nunavut's financial support flows from the federal government in the form of massive transfer payments to the territorial government, which is then responsible for administering social services in the territory, including education. Hamlet councils-consisting of a mayor and eight councillors-have responsibilities relating to "roads, budgeting, animal control, building standards, water \& sewage services, recreation, employment, etc." ${ }^{8}$

In addition, land claims organizations constitute a fourth layer of governance. Overseeing the implementation of the NLCA is the Nunavut Tunngavik Corporation (NTI), which is considered to be the largest and best funded land claims organization in Canada (Hicks \& White, 2015, p. 81). Under the auspices of NTI are three regional Inuit organizations 
(RIAs), which are in turn made up of investment and development corporations and various associations. For purposes of this discussion, the Qikiqtani Inuit Association (QIA) is headquartered in the territorial capital of Iqaluit. QIA manages Inuit-owned lands in the Qikiqtaaluk (Baffin) region on behalf of approximately 14,000 beneficiaries who live in thirteen communities from Quttiktuq in the High Arctic down to Sanikiluaq located in Hudson Bay. ${ }^{9}$

As Ritsema et al. (2015) note with respect to Nunavut's multilayered system of governance, the "convoluted system of competing interests, perspectives, and goals" has resulted in confusion amongst local communities, which lose track of who is responsible for what service or policy impacting their lives. This confusion is extended to provision for vocational education and training, including programs and institutions associated with the MRIIBA as identified in Article 8.1.6. As Caine and Krogman (2010) note, by channelling Indigenous groups and industry players into contractual agreements, the federal government has "abrogated its fiduciary responsibilities to Aboriginal people in the North for education and training by not knowing what is needed, or agreed to, within IBA's" (p. 88). At the territorial level, Nunavut's devolution policy also contributes to an ad hoc delivery of vocational education and training. Nunavut Arctic College has three regional campuses and twentyfour community learning centres. Owing to devolution, a trades training centre is located in only one region-at Rankin Inlet's Kivalliq campus. This stands to reason given Nunavut's sparse population. However, the MRIIBA requires that local labour be preferentially hired. This means that other than funding short-term programs at community learning centres, resource developers are more likely to provide on-site training rather than develop third party agreements with the college if training cannot be offered in communities. Residents who do not live in the Kivalliq region are therefore constrained in terms of accessing vocational education opportunities.

With respect to the formation and implementation of the MRIIBA, Ritsema et al. (2015) also note that community members in Mitmattilik distrust their RIA owing to a lack of transparency and communication relating to royalties from the project (p. 169). Similar tensions existing between land claims organizations and community members have been noted in other regions where IBAs have been brokered (Caine \& Krogman, 2010; Cameron \& Levitan, 2014; Kulchyski \& Bernauer, 2014)-one possible indication of the emergence of a comprador element occurring within the region. As Mitchell (1996) explains: 
Although the development corporations are becoming increasingly important as employers of Inuit, their main significance is that they control the allocation of resources and wealth, and that their economic control is combined with political control [my emphasis]. I suggest that what has occurred is an incorporation of Inuit into the Canadian class structure, but it is an unequal incorporation because the capital controlled by the ruling class is not self-generated [my emphasis], and because the "inferior" ethnic status of the ruling class acts as a check to its involvement in mainstream industrial development and meaningful involvement at the political level. (p. 398)

Mitchell's description of an Inuit "ruling class" is useful when considering communication gaps existing between community members and RIAs that have formed in the wake of IBAs. Moreover, Mitchell's characterization also alludes to the rentier-like system of incentives now structuring new social relations. As Beblawi (1987) explains, rentierism exists where: 1) rent situations predominate; 2) substantial external rent is capable of sustaining the economy without a strong productive domestic sector; 3) only a few are engaged in the generation and control of this rent, with the majority involved in the distribution or utilization of it; and 4) the government is the principal recipient of the external rent, affecting the role of the state in the economy. That is to say, "capital controlled by the ruling class [that] is not self-generated" represents passive forms of capital accumulation, i.e., economic "rents."

Formation of a rentier class does not mean to suggest that land claims organizations are not concerned with other aspects of IBAs beyond that of rent-seeking, such as mitigating the adverse effects of a mining development, or having people they represent gain employment. Yet, owing to the education deficit of beneficiaries, the principal "benefit" that can be derived from resource development remains that of accessing economic rents. Hence, the structuring effects of rent-seeking may inadvertently relegate training and employment as an afterthought to development; once a project is granted approval, low employment rates are used politically to leverage further rents during the course of the mining life cycle.

Evidence of rent seeking behaviour is found in media reports illustrating the inversely proportional relationship existing between the multimillion-dollar flow of resource rents and the decline in Inuit employment numbers - a paradox that is occurring despite project 
expansion (Ducharme, 2017). When tensions do arise between land claims organizations and industry, they usually involve quarrels over greater access to rents (Gregoire, 2016; "Inuit Org names Thomas Berger," 2016; Klein, 2016; Hicks \& White, 2015, pp. 48-49). And when disputes involving Inuit participation rates at mines are raised, rather than recognizing and addressing the low educational attainment and skills of those seeking employment, the solution involves politically expedient and vague establishment of unrealistic "minimum Inuit employment goals," as well as improved "work-readiness" programs ${ }^{10}$ that get popularly touted as "training" rather than as measures to screen applicants (Bell, 2017; Brown, 2017; Gregoire, 2017; Leite, 2017; Skura, 2016).

\section{Method}

Mittimatilik (Pond Inlet; $72.7^{\circ} \mathrm{N}, 77.9^{\circ} \mathrm{W}$ ) was chosen as the case site as it is both the most populous North Baffin community (pop. 1617; 90\% Inuit ${ }^{11}$ ), and it is located nearest to the Mary River project (approximately $160 \mathrm{~km}$ southwest). Politically, it is classified as an incorporated hamlet. Like most communities, Mittimatilik's formal economy is service-based, with public administration, retail trade, educational services, construction, health care, and social services sectors dominating labour force participation (Statistics Canada, 2013, cited from Ritsema et al., 2015). Subsistence hunting, fishing, and gathering, as well as the practice of cultural arts, are also important parts of the overall economy (Ritsema et al., 2015). Mittimatilik has an elementary and junior high/high school, as well as a community learning centre that offers programs and courses for adults. Like many communities in Nunavut, Mittimatilik struggles with poverty as noted in a variety of social indicators, including low educational attainment, high unemployment, and poor health (Brubacher, 2015a; Ritsema et al., 2015).

The research inquiry was extended over the course of two summers (July 21-August 08, 2015; July 4-21, 2016), and anchored to a particular phenomenon-local training and employment with the project. Two different sets of interviews involved stakeholders and people who were either currently employed or seeking re-employment with the project (workers). Extending the case study allowed for a more nuanced understanding, as ongoing conversations provided deeper insight-a technique that was especially useful with workers, where second interviews provided an opportunity to clarify or elaborate upon comments shared the previous summer as well as to gauge outcomes of learning-towork transitions. 
A total of forty-eight interviews and one focus group were conducted with workers using semi-structured and open-ended interviews. Of the initial twenty-two workers interviewed in 2015, fourteen were subsequently interviewed the following year; information concerning the status of five workers was also provided through word-of-mouth, and no information was gained about the status of three individuals. An additional worker was also interviewed once in 2016.

Eleven interviews and two focus groups were also conducted with stakeholders during both phases of the field work. Stakeholders included community members involved in education and health care, residents who had a longstanding knowledge of the community, and representatives from various levels of government, including municipal, regional, territorial, federal, and Inuit organizations. While several conversations occurred with mine representatives, no formal interview was granted. In addition to stakeholder interviews, other informal conversations and observations, including those made during community and regional socio-economic meetings, occurred throughout the inquiry.

Recruitment of worker interview participants initially occurred with the assistance of hamlet council employees, as well as the use of a community Facebook site and local radio announcements; thereafter participants were recruited through word-of-mouth (snowball sampling). Most interviews occurred at the hamlet office, although some interviews also occurred in other public places $(n=4)$ and residences $(n=3)$. Initial interviews lasted for approximately thirty to forty minutes, with questions focusing on work experience, levels of training and education, lifestyle, and career aspirations. Follow-up interviews were subsequently tailored to different individual circumstances, and lasted between twenty and fifty minutes. Questions concerned the degree to which workers were successful in fulfilling the education and career goals they had initially identified, and whether or not they were successful in gaining employment, receiving training, or getting job promotions.

Most interviews were audio recorded, while eight interviews relied solely on note-taking. Several interviews $(n=5)$ required the assistance of an interpreter. In three cases a hamlet council employee was able to offer assistance; in two cases an employee at a government building offered assistance.

Prior to being interviewed, all participants received an explanation of the research purpose. A copy of the letter explaining the research and ethical considerations was also provided and signed by participants. At the end of each worker interview a gift certificate from the local Co-op was 
offered as a thank you. A copy of the transcript was sent to each participant to verify accuracy of the contents, and to provide an opportunity for participants to withdraw or make changes to the transcript. Preliminary findings were presented at a community meeting, as well as to an Inuit organization in Iqaluit in 2016. These meetings provided an opportunity to gain important feedback that helped to triangulate findings.

Limitations of the case study include a sample size of workers that is disproportionately comprised on unemployed former mine employees. It is reasonable to conclude that their employment status may have contributed to a sense of disaffection that is reflected in many of the interviews. A second limitation was the language barrier, as several interviews, focus groups, and meetings required the use of translators, which most likely contributed to miscommunication in some cases. The follow-up interviews mitigated these limitations and provided an opportunity to clarify previous comments.

The findings and results presented here are organized into two sections: 1) worker demographics relating to employment with the project; and 2) experiences of workers relating to recruitment, training, and termination. Stakeholder interviews are incorporated as a means of providing additional context to the perceptions shared by workers. For purposes of providing a coding designation, "W" designates worker (e.g., W-1 refers to worker 1 ).

\section{Worker Demographics}

Most workers $(n=23)$ were men $(n=19)$ whose ages ranged from twentyone to sixty-three; the majority were in their twenties. In terms of their employment history with the project, workers were organized into four cohorts: Cohort 1 ( $n=5 ; 4$ men, 1 woman) were continuously employed at the time of interviews; Cohort 2 ( $n=4 ; 3$ men, 1 woman) were employed and subsequently laid off between interviews; Cohort 3 ( $n=12 ; 10$ men, 2 women) had been laid off for over a year; and Cohort $4(\mathrm{n}=2)$ had never gained employment, but had applied. Whereas Cohort 1 workers are characterized as having relatively high job security, the other cohorts experienced job insecurity. By combining the last three cohorts together, job insecurity reflects the majority of interview participants $(n=18)$.

In Cohort 1, all men were employed as heavy equipment operators (HEO). Duration of employment ranged from two to three years, and one individual (W-17) had been employed with the project since 2002. One woman (W-13; aged 46), who had been a housekeeper for the past three 
years, reported that she had been on medical leave and was returning to her job the following week.

In Cohort 2, duration of employment ranged from four months to six years. All workers had been employed by contractors, although one employee (W-2) had also worked for the mine and was a general labourer for one-and-a-half years; W-6 had worked as a dishwasher and general labourer for six years; and W-21 had been an HEO for two years. The female worker (W-23) had been employed in service support as a baker's assistant, housekeeper, and dishwasher for four months.

Most Cohort 3 workers had worked for a contractor $(n=9)$ and were employed on a temporary "seasonal" basis in service support (dishwashers, assistant cooks, janitors, housekeepers). The term of employment for contract employees ranged from one month (two rotations) to six years, with an average duration of one-and-a-half years. Three workers had worked for the project in the following positions: Community Liaison Officer (four years), Administrative Assistant (three months), and HEO (six weeks). Duration of employment ranged from one month to four years. Cohort 3 workers had been employed from 2008 to 2014. However, most indicated that they were last employed at the project in 2013 and $2014(\mathrm{n}=5)$.

In Cohort 4, two people had never worked for the project, but indicated they had applied. One man (W-19) had applied for a managerial position, but was incarcerated at the Baffin Correctional Centre between interviews, while the other man (W-10) did not respond to my request for a second interview. In this case, it is assumed he is not working at the project. Figure 1 summarizes the occupations reported by cohorts 1 to 3 .

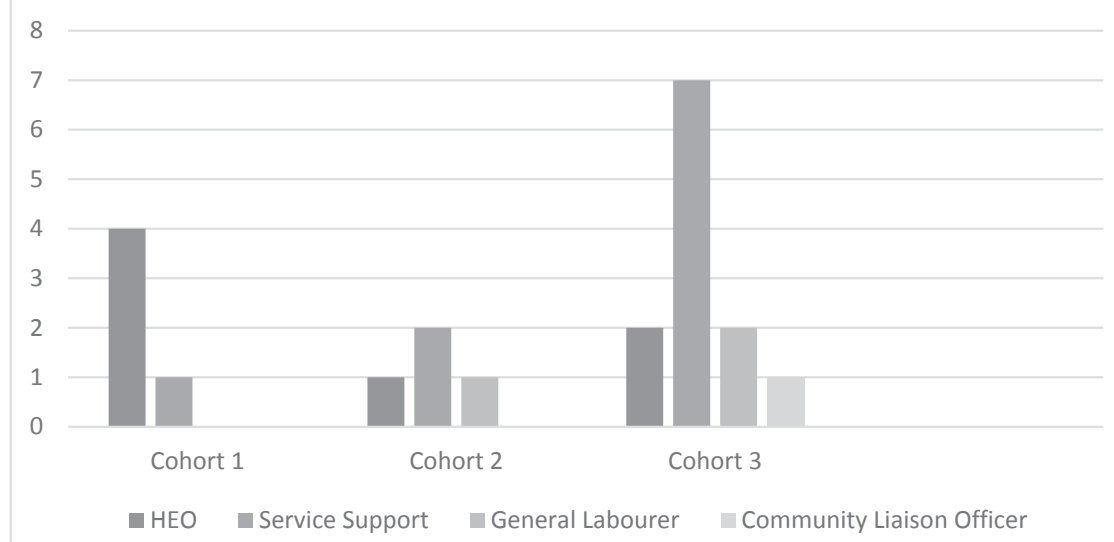

Figure 1. Project occupations reported by workers 


\section{Worker Experiences}

Most workers expressed positive attitudes about the project, with many indicating that they wanted to return to work. The experiences of workers included topics relating to recruitment and retention; the nature of fly-in flyout shift work (including impacts on family dynamics); income; spending habits; and education and training. Considering that most workers interviewed were no longer employed with the project, conversations focused upon challenges that preclude further employment. Emerging from these perceptions was a dominant theme of miscommunication. It became evident-particularly in the second community visit - that many workers and some community stakeholders saw the research as an avenue to express frustrations over what they considered to be a chief failing of the MRIIBA - a breakdown in communication between beneficiaries and the agreement signatories. Areas of miscommunication primarily related to recruitment, retention, and termination of employment. What follows are select passages from interviews that help to capture the perceptions of workers, as well as the gaps in understanding and communication that existed.

\section{Recruitment}

The cumbersome and impersonal application process represented a barrier for several workers. This process often required workers to submit their application online where it would then be processed by someone they had never met in southern Canada. Many workers stated that they never heard back regarding the status of their application. Distrust with the hiring process was often expressed, which in turn contributed to a sense of apathy and despair.

The opportunities are not really around... I think that's why we don't have the qualifications to work in Baffinland with the lack of jobs up here.

How do people feel about that?

I think they just give up and don't bother to try again. (W-16, 2015)

I applied there for Baffinland, but I don't know what happened. I did apply twice but ... no luck. (W-5, 2015) 
And you've been waiting nearly a year, and you have not heard back?

Yes.

So, why have you not heard back I wonder?

That's what I want to find out too. Like I never heard back saying you didn't get the job or you're not; not a word back from them.

My understanding is that the Inuit have preferential employment at the mines.

Yep, like they're saying that right? It's better for Nunavut beneficiaries to get a job easier. Still got no reply. I heard lots of people applied too. Never got a reply. (W-10, 2015)

They [contractor ${ }^{12}$ ] said they would call me and I kept waiting. They didn't reply.

Is [RIA] helping you?

No. Just long-distance call.

And what are they saying?

They told us - keep waiting - nothing has happened. (W-15, 2015)

Several workers also felt that the community liaison officer responsible for facilitating employment with the project was unapproachable and preferentially hired select people. ${ }^{13}$ For instance, W-18 (2016) told me that he would like to work at the project again, but said that the officer thinks that he is "lazy." W-18 was told that he needed to get a medical certificate, which he then submitted, but has yet to receive a response. These observations indicate that blame over failure of the project to fulfill the IIBA was often directed towards members of the same community, rather than to the project itself.

\section{Education and Training}

The highest grade levels achieved fell into the following groups: less than a Grade $10(n=7)$; Grade $10(n=8)$; Grade $11(n=3)$; and Grade 12 $(n=3) .{ }^{14}$ However, several community educators indicated the grade levels reported would not be commensurate with provincial levels of achievement. Reasons for this discrepancy included a policy of passing students along with their peers ("social pass"), and limited course offerings - with English 30 the only academic Grade 12 course offered at the high school. 
Some interviewees mentioned changes to the way skills are assessed, which in turn impacts access to mine-related employment. Whereas people were once screened on demonstrable skills, credentialing now precludes workers from accessing the same jobs. This means that older workers are able to access better jobs (and pay) as they have been able to gain experience that younger workers are unable to access owing to credentials they do not have on account of their formal educational attainment. These observations appear to contradict Article 7.3.2 of the MRIIBA (2013), which states "Where appropriate, the Company will consider ability, skills and experience as an equivalent to formal qualifications, and Inuit applicants with experience equivalencies will be treated equally with all applicants with formal training" (p. 53).

When asked about supports to get further education or training, most workers were unclear of where to get assistance, or the career paths that were needed to achieve stated career aspirations. Those that were able to articulate clear linkages between education, training, and employment were younger males in Cohort 1.

Where would you apply for that [training]?

Guess through Arctic College, or I don't know where I would apply, just pretty lost right now in Pond. (W-10, 2015)

So, you don't know what the qualifications were, or how to get them if you want to work?

I'm not sure how to get those qualifications.

How about going to Arctic College - is that part of it?

I've been meaning to go back to school. (W-16, 2015)

As the above two passages suggest, the relationship between the college and project had not significantly developed at the time of interviews. Nunavut Arctic College offers programs that are tied to funding. And owing to Nunavut's devolution policy, resources are spread thin throughout the vast territory, meaning that some courses are not always offered at community learning centres. As one stakeholder explained, those that are offered are cheaper and less complicated to run owing to available personnel and housing. Several community stakeholders also noted that some courses are readily offered (e.g., Office Admin, the Teacher Education Program, Adult Basic Education); whereas programs like the Environmental Technology Program (funded by the company during the second year) was considered too expensive to run 
a second time, despite reportedly graduating eleven students (compared with two from the teacher education program). ${ }^{15}$ A sixteen-week pretrades program was offered the previous year, yet only two of the nine students who participated passed the Trades Entrance Exam. ${ }^{16}$ Some stakeholders also felt that a greater emphasis on trades was needed in the school in order to generate further interest for students.

On-the-job training offered by the company includes the following: 1) operations procedures (e.g., site orientation); 2) health and safety (e.g., First Aid); 3) spill response (cleanup and reporting); 4) supervisor training for those with experience as managers; 5) other areas also include HEO assessment and training (Brubacher 2015b, pp. 10-11). With respect to on-the-job training, some workers were able to articulate opportunities. However, rather than providing a clear sense of career pathways, recollections were oftentimes vague or noncommittal:

And do you see yourself continuing as a dishwasher and as a housekeeper, or do you see yourself getting other types of work there?

To be honest, I don't know. Keep working as a dishwasher and a housekeeper until I can see what the money to go to a bakery course.

To take a bakery course? And would [your employer] be able to support you in doing that, in taking that course? Would they be able to train you or get you sent out for training?

I was talking to my supervisor about that but they were very busy, and didn't have much time so I didn't really get my answers. (W-2, 2015)

So you're a heavy equipment operator?

Yeah

And when you say they trained you up, what does that mean?

I was in the classroom and the paperwork, simulators - they have simulators for the equipment.

Oh right, they have the classroom component.

At main camp site.

How long was that for?

Good month training back-and-forth in-and-out of the field, and in the class.

Did you get a certificate out of that?

Just based on test, test score at the end, yeah.... 
Would you be interested in getting more training?

Yeah, I'm always wanting to learn more.

And what's the opportunities for more training? Or did they talk to you about that?

Yeah, there's uhm, site supervisor, yard supervisor, the crew that's out in the oilfield, there's the office department, exploration, geology, other departments where they need your diplomas

Are you looking to enter into a trade?

They offer all. There was talk of offering apprenticeship grants in other departments, mechanics electrician stuff like that if the mine grows. (W-12, 2015)

A year later, W-12 had taken a three-month unpaid leave to sort out family tensions and to help raise his children. He also informed me that his circumstances required that he quit his job, and he was subsequently not eligible to apply for Employment Insurance.

With respect to apprenticeships and trades, Brubacher (2015b) reports that in 2014, one-third of all work performed at Mary River fell into the construction and maintenance trades areas, yet only $2 \%$ of this work was performed by Nunavummiut (p. 12). The one worker (W-14) who was able to articulate aspirations of entering into a trade described his work situation this way:

I'm a fuel truck driver waiting on being apprentice mechanic.

You're the first person that I've talked to who is talking about apprenticeships ... you're also the first person I talked to that's gotten their Grade 12 education. So, is there a relationship between getting your Grade 12 and apprenticing?

Ah, yeah sort of. I would like to get into that kind of stuff like apprentice.

And where did you hear about the apprenticing? Did they approach you at [the project]?

Yeah, they did when they were interviewing, and talking about the mine opening again. They were saying there's going to be apprentice jobs and training at the work site, so I went ahead with fuel truck driver since that's part of maintenance which is with the mechanics, welders and, so got to work alongside mechanics and welders, and people like that.

Did they approach you about apprenticing, or did you approach them? 
Well, I asked them about it, and then after my work probation they asked me if I wanted to get into trades, and I went with it. (W-14, 2015)

A year later, W-14 informed me that there was a "barrier in getting my apprenticeship" that had to do with writing the Trades Entrance Exam - an exam that he had once written, but which had now "expired." Challenges in passing the exam related to mathematics, which he felt the local college could assist him with. However, making time to study was challenging: "there's also family time; it gets very stressful ... I was already signed up for over-time, and so I did not work on the course work."

This worker's unfortunate set of circumstances illustrates the precarious learning-to-work transitions accompanying shift work. It also underscores the importance of establishing support systems for prospective apprentices. A component of on-the-job training should therefore include appropriate time to upgrade, which, as the above passage indicates, cannot be realistically completed during time off when workers need to rest and attend to other responsibilities.

\section{Termination}

Numerous former workers took the opportunity during follow-up interviews to express their frustration and resentment over what they perceived to be unfair termination practices. Grievances primarily related to the lack of communication occurring between employers and employees, as well as the absence of support systems as it was perceived that they had no one to advocate on their behalf once their employment was terminated. Reasons for termination cited by Cohort 2 workers included interpersonal disputes with the immediate supervisor (W-23); accusations of substance abuse (W-2); failure to sign an accident report (W-6); and taking an extended six-week absence for personal family reasons (W-21). All male workers contested their termination and filed complaints, but had not heard back from their employer at the time of follow-up interviews. Similarly, most respondents in Cohort 3 presented a combination of reasons for termination including the following: child care (1), jury duty (1), criminal record (1), workplace accident (1), contract ending (1), tardiness (1), disputes with co-workers/supervisors (2), illness (2), and substance abuse (4). Most workers indicated that they wanted to return to work.

These reasons belie the communication gaps between workers and those organizations responsible for hiring and supporting them. One 
worker, who had also been a recruiter for the project, matter-of-factly shared these insights: "We are at the mercy of the Company... The feds have not been helping out in areas of grievances ... and the [RIA] director would hear a story [of termination] and do nothing" (W-4, 2016). $\mathrm{W}-4$, also considered that very few people trust "those guys [RIA] who are representing us." He indicated that the IIBA is only accessible by computer, and very few people in the community have internet access.

Evidence of the poor communication and lack of advocacy for workers can be seen in the following conversations:

Why did you stop working for Baffinland?

They let me go because they thought I was smoking weed in the building even though I told them I never did. And there was this fire alarm that sticks out in the rooms ... It was sticking out, forgot to report it as soon as I got in. It was just hanging in the ceiling and I forgot to report it about it so they thought I took it out and they thought I smoked up in my room. (W-9, 2015)

A year later W-9 indicated that the employer required that he take a forty-two day drug rehabilitation course in Edmonton before he returned to work. He honoured the request, and upon completion of the program re-applied for work, but still has not heard back.

My conversation with W-11, illustrates other communication challenges impacting her return to work.

Can you tell me why you're not working for Baffinland now?

What happened?

I wasn't well to keep working.

What did your employers say?

The employer said for doctor's note and fax.

A fax of the doctor's note?

Yes

And were you able to provide that?

No, there's no doctors in town. We have to have a certain reason to make an appointment for the doctor. There's no doctors.

That was a while ago. That was a year and a half ago.

Yes.

So, you're still waiting for a doctor's note? 
Yes. I'm still waiting for a doctor's note. I have been requesting for that note. And I also don't know what is, they want me back or they don't want me back. I have never received a phone call or any information regarding my employment from Baffinland.

(W-11, 2015)

A year later I was informed that this person was in an Ottawa hospital; she was critically ill and paralyzed from the neck down.

A similar tragic circumstance accompanied the untimely termination of another older worker (W-21). In a follow-up interview I learned that he was terminated when he took a six-week break to help his wife whose older sister was dying of cancer. According to W-21, he explained the situation to the employer but was terminated two days after the funeral: "They said they would call back, but they never did." He wrote a letter of complaint, and asked for two million dollars in compensation. When I asked him how he came up with the figure, he was unable to provide a reason - "it just seemed the right amount." W-21 informed me he was recently diagnosed with lung cancer, and he won't be able to work again.

By chance, I was driven to W-21's house by a community leader who later took it upon himself to organize a community meeting for me to present preliminary findings. The meeting lasted ninety minutes and was attended by fifteen people. During the meeting he spoke about his frustrations with the RIA, indicating that the IBA coordinator only visits small communities once or twice a year; and the RIA education and training coordinator does not visit small communities at all, claiming they are "just sitting in their office in Iqaluit with nothing to do, implementing the Agreement" (meeting notes, 14 July 2016). The meeting provided an opportunity for community members to raise similar concerns regarding their own personal or family-member circumstances.

The next day, I attended the annual socio-economic monitoring committee meeting that was held in Iqaluit. The stated purpose of the meeting was to "assist industry proponents fulfill project certificate conditions and keep impacted communities routinely informed of project activities. The meetings provide communities a venue to share experiences and observations, ensuring dialogue between industry and impacted stakeholders remains open and transparent (email communication, government employee, 15 July 2016). Various community representatives took the opportunity to raise questions and concerns similar to the ones 
described in this article. No senior Mary River project or land claims organization representatives were in attendance.

\section{Conclusion}

This article has investigated various sources of miscommunication that undermine training provisions and employment outcomes of the MRIIBA. As I have shown, miscommunication existing between workers and employers is a symptom of overarching, systemic, regional problems. As such, micro-social relations, as shared through the perspectives of workers and stakeholders, have been situated within the macro-structural forces impacting these relations.

At the micro-social level, factors contributing to miscommunication between workers and employers includes cross-cultural differences relating to conflict resolution, language barriers, and family responsibilities. These forms of miscommunication contribute to misunderstandings relating to recruitment, training, and termination of employment. Consequently, there is an urgent need to ensure on-the-ground supports are in place to rectify problems immediately. Relatedly, considering the high turnover rates and termination of workers, "work ready programs" should have a section outlining worker rights, including who they can contact when problems arise. These measures are especially important given the region's geographic remoteness and the absence of a union.

Compounding problems of miscommunication between workers and employers is the capacity of various stakeholders to implement the agreement, which in the areas of training and employment remain largely ineffectual aspirational platitudes. High turnover rates experienced by the project, government, and Inuit organizations erode the capacity to effectively communicate, as both the commitment to uphold the nature of the agreement, as well as the institutional memory to enact it, are lost with each change in personnel. In turn, weak internal capacity leads to weak linkages between the various stakeholders-linkages that are needed in order to fulfill training provisions of the agreement. Effective learningto-work transitions therefore require both institutional capacity and stakeholder linkages to be developed before agreements are in place.

These somewhat obvious aspects contributing to miscommunication and their corollary solutions, nevertheless belie more problematic aspects that have become entrenched as part of the regional political economy. This article has argued that the neo-liberal approach to the state "steering 
at a distance" has not worked. As a feature of neo-liberal governance, IBAs contribute to the ad hoc delivery of programs. This is because funding is contingent upon the machinations of the market, rather than being tied to stable and predictable sources that are needed to allow programs to develop over the long term. By channelling Inuit into agreements with resource developers, the state has also effectively abrogated its fiduciary responsibilities to address the inordinately low education achievement of most Nunavummiut. Before Inuit can effectively participate in wage employment, far greater resources must be provided by the state, especially in the areas relating to housing, health, and education.

Less obvious aspects of neo-liberal governance are class divisions that have formed in the wake of land claims. Despite the fact that local employment has not improved, and hence the material benefits have not flowed to ordinary Inuit who are being dispossessed of their lands, land claims organizations have nevertheless significantly increased their access to rents. The intention of highlighting this dichotomy is not to cast aspersions on self-determination. Rather, it is to identify barriers that continue to hamper participation in wage labour employment-which outside of government bureaucracy largely remains the purview of the resource extractive industries. And because class interests are entrenched through established rent-seeking behaviours, education will inevitably remain an after-thought to development. As noted by the troubling comments of workers, a secondary effect of these divisions is the absence of advocacy and support systems.

Maintaining community-based monitoring that is developed in partnership with community members and other supporting organizations independent of IBA signatories will help ensure that lines of communication are open. Long-term community monitoring will increase levels of trust and communication needed to gain accurate and reliable information that can then be used to identify communication gaps between what is being presented by IBA signatories and what is being understood by workers. 


\section{Acknowledgements}

This research was supported by grants from the research network, Resources and Sustainable Development in the Arctic (412- 2011-1006), Social Sciences and Humanities Research Council of Canada, and from the Nunavut General Monitoring Program (1213-01-000144), Aboriginal Affairs \& Northern Development Canada. I would also like to thank the three anonymous reviewers for their excellent, insightful comments.

\section{Author}

Andrew Hodgkins, $\mathrm{PhD}$ is an independent researcher in Edmonton, Alberta. During the time most of this research was conducted, he was an adjunct professor (July 2015 to June 2017) in the Department of Educational Policy Studies, University of Alberta. Contact hodgkins@ualberta.ca

\section{Notes}

1. Eighteen of these agreements include self-governance provisions. Aboriginal groups may enter into either "specific claims" or "comprehensive claims" with both the federal and provincial or territorial governments. Specific claims deal with grievances related to Canada's obligations to honour historic treaties, and do not necessarily involve land. Comprehensive claims, on the other hand, are considered "modern day treaties," as they involve negotiating settlements with Indigenous peoples who never signed a treaty; comprehensive claims always involve land. (GoC, n.d.).

2. David Harvey (2005) defines neo-liberalism as "a theory of political economic practices that proposes that human well-being can best be advanced by liberating individual entrepreneurial freedoms and skills within an institutional framework characterized by strong private property rights, free markets, and free trade. The role of the state is to create and preserve an institutional framework appropriate to such practices (p. 2).

3. A beneficiary is an Inuk who meets various conditions outlined in Article 25 of the NLCA (Nunavut Tunngavik Inc., 2004, p. 69).

4. Royalties will not begin to flow into communities until the mine produces at $60 \%$ of its production capacity, which is $1.19 \%$ of net sales of ore (see Quenneville, 2016).

5. Information about IIBAs from the Nunavut Tunngavik website: http://nlca. tunngavik.com/?page_id=2444\&lang=en

6. "Metal mining is the single largest contributor to economic growth, and all operating mines are planning increases in production," stated an August 1 report from the conference board on all three territorial economies (CBC, 2017). In 2017 CBC reported that mining output will grow by $23.7 \%$, following the opening of TMAC Resources Inc.'s Doris North mine in the Kitikmeot, and increased production at Baffinland Iron Mines Corp.'s Mary River mine and Agnico Eagle Ltd.'s Meadowbank (CBC, 2017). 
7. As part of the settlement, Inuit surrendered Aboriginal title to $80 \%$ of the territory's 1,750,000 $\mathrm{km}^{2}$ in return for financial compensation and certain defined rights over wildlife and other resources. Nunavummiut have title to $350,000 \mathrm{~km}^{2}$ of land $\left(36,257 \mathrm{~km}^{2}\right.$ with subsurface mineral rights).

8. Information from Nunavut Municipal Councillors Handbook: https://www. nmto.ca/sites/default/files/nunavut_municipal_councillor_hb_01_06eng_0. pdf.

9. Information from the QIA website: http://qia.ca/about-us/

10. The first iteration of the Work Ready Program was delivered in 2013 and it focused on four modules: 1) preparing for fly-in fly-out employment; 2) communication at work and at home; 3) money management; 4) managing stress. No mention of workers' rights is included in the program. Of the 2,903 hours of reported training delivery for Inuit at the Company in 2014, thirty-six hours were devoted to "Human Rights in the Workplace" (Brubacher, 2015b, p. 10; see also Brubacher, 2015a, p. 50).

11. Census Profile, 2016 Census, Statistics Canada (February, 2017). Retrieved from http://www12.statcan.gc.ca.

12. These perceptions were countered by a contractor who expressed frustration over working very hard with clients who then quit the job site; most of these clients were considered to have addictions.

13. In 2007, the company established liaison officer positions and offices in the five communities in the North Baffin to organize and facilitate employment (Brubacher, 2012, p. 2).

14. Most workers quit school in Grade 10 for a variety of reasons. These included gaining a full-time job in order to help support family members (and in some cases due to the responsibilities of starting a family). Others cited reasons for entering the workforce in order to purchase a snow machine, or because their peers had suggested it. Some workers also dropped out of school because they had either fallen too far behind in their studies, or were experiencing unresolved conflicts with peers or staff.

15. According to one community stakeholder, two of these graduates were currently employed by the project.

16. Trades entrance exams are administered by apprenticeship officers and are designed to prove that apprenticeship candidates have the basic educational requirements for technical training in a particular trade. This exam is commonly cited as a significant barrier for Indigenous workers to enter into a trade (Hodgkins, 2013; Brubacher, 2015a). 


\section{References}

ASEP (Aboriginal Skills and Employment Partnerships), n.d. Retrieved from http://aboriginalskills.ca/_downloads/ASEP_1pager.pdf

Beblawi, H. (1987). The rentier state in the Arab world. In H. Beblawi and G. Luciani (Eds.), The rentier state (pp. 49-62). London, UK: Croom Helm.

Bell, J. (2017, May 9). QIA to push hard for Inuit employment at Mary River. Retrieved from http://www.nunatsiaqonline.ca/stories/ article/65674qia_to_push_hard_on_inuit_employment_at_mary_river/

Bell, J. (2012, April 20). Meadowbank a reality check for Nunavut mining: AEM executive. Retrieved from http://www.nunatsiaqonline.ca/stories/ article/65674meadowbank_a_reality_check_for_nunavut_mining_aem_ executive/

Berger, T. (2006, March). Conciliator's Final Report: "The Nunavut Project." Retrieved from http://www.cba.org/nunavut/pdf/NU_finalreport.pdf

Brown, B. (October 10, 2017). Inuit org hopes to boost job numbers at Mary River. Retrieved from http://www.nunatsiaqonline.ca/stories/ article/65674inuit_org_hopes_to_boost_inuit_job_numbers_at_mary_river/

Brubacher, D. (2015a). Pond Inlet: The state of our community (Background report in support of the Community Readiness Initiative). Ottawa: Brubacher Development Strategies, Inc.

Brubacher, D. (2015b). Baffinland Iron Mines Corporation Mary River Project: 2014 Socioeconomic monitoring report, March 2015. Ottawa: Brubacher Development Strategies, Inc.

Caine, K., \& Krogman, N. (2010). Powerful or just plain power-full? A power analysis of impact and benefit agreements in Canada' North. Organization $\mathcal{E}$ Environment, 23(1), 76-98.

Cameron, E., \& Levitan, T. (2014). Impact and Benefit Agreements and the neoliberalization of resource governance and indigenous-state relations in northern Canada. Studies in Political Economy, 93, 25-52.

Conference Board of Canada (2017). Territorial outlook economic forecast: Summer 2017. Ottawa: The Conference Board of Canada.

Dalseg, S., \& Abele, F. (2015). Language, distance, democracy: Development decision making and northern communications. The Northern Review, 41, 207-240. https://doi.org/10.22584/nr41.2015.009

Ducharme, S. (2017, July 7). Tribunal rules Inuit org should receive back pay from iron mine. Retrieved from http://www.nunatsiaqonline.ca/stories/ article/65674tribunal_rules_inuit_org_should_receive_back_pay_from_iron_ miner/

GoC (Government of Canada). (n.d.). Land claims. Retrieved from https://www. aadnc-aandc.gc.ca/eng/1100100030285/1100100030289 
GoC (Government of Canada). (2000). Gathering strength: Canada's Aboriginal Action Plan. Ottawa: Indian Affairs and Northern Development.

GoC (Government of Canada) (2009) Federal framework for Aboriginal economic development. Ottawa: Minister of Indian Affairs and Northern Development. Retrieved from https://www.aadnc-aandc.gc.ca/ eng/1100100033498/1100100033499

GoC (Government of Canada) (2013). Budget 2013 (Private sector participation in Aboriginal training). Retrieved from https://www.budget.gc.ca/2013/doc/ plan/chap3-1-eng.html

GN (Government of Nunavut, 2017). Stats update. Retrieved from https://www. gov.nu.ca/sites/default/files/nunavut_and_canada_population_estimates_ statsupdate_third_quarter_2017.pdf

Gregoire, L. (2016, October 7). More tit-for-tat accusations emerge between Inuit org and Nunavut mine. Retrieved from http://www.nunatsiaqonline.ca/ stories/article/65674more_tit-for-tat_accusations_between_inuit_org_and_ nunavut_mine/

Harvey, D. (2005). A brief history of neo-liberalism. New York: Oxford University Press.

Hicks, J., \& White, G. (2015). Made in Nunavut: An experiment in decentralized government. Vancouver, BC. UBC Press.

Hobart, C. W. (1982). Inuit employment at the Nanisivik mine on Baffin Island. Études/Inuit/Studies, 6(1), 53-74.

Hodgkins, A. P. (2013). Regulation of vocational education and training fields in northern Canada (Doctoral dissertation, University of Alberta, Edmonton). https://doi.org/10.7939/R3RV0DB55

Inuit org names Thomas Berger to help fix $\$ 6.25 \mathrm{M}$ spat with mining company (2016, September 7). Retrieved from: http://www.nunatsiaqonline.ca/stories/ article/65674inuit_org_appoints_thomas_berger_in_6.2m_dispute_with_ mining_company/

Klein, G. (2016, October 5). Inuit org launches legacy fund for $\$ 24$ million in mine royalties. Retrieved from http://resourceclips.com/2016/10/05/ inuit-org-launches-legacy-fund-for-24-million-in-mine-royalties/

Kulchyski, P., \& Bernauer, W. (2014). Modern treaties, extraction and imperialism in Canada's Indigenous North: Two case studies. Studies in Political Economy, 93 (Spring), 3-23.

Leite, J. (2017, November, 28). Baffinland launching work ready program in Igloolik to help prepare Inuit for work at Mary River Mine. Retrieved from http://www. baffinland.com/latest-news/baffinland-launching-work-ready-program-inigloolik-to-help-prepare-inuit-for-work-at-mary-river-mine/?lang=en

Mitchell, M. (1996). From talking chiefs to a native corporate elite. Montreal: McGillQueen's University Press. 
Quenneville, G. (2016, May 23). Nunavut group shows its members the mining money. Retrieved from http://www.cbc.ca/news/canada/north/ nunavut-unit-mining-money-1.3596102

Palesch, N. (2016). Creating opportunity in Inuit Nunangat: The crisis in education and labour market outcomes. Retrieved from http://www.csls.ca/reports/ csls2016-12.pdf

Rata, E. (2005). Rethinking biculturalism. Anthropological Theory, 5(3), 267-284. https://doi.org/10.1177/1463499605055960

Rata, E. (2003). Late capitalism and ethnic revivalism: A new "middle age"? Anthropological Theory,3(43),43-63.https://doi.org/10.1177/1463499603003001751

Ritsema, R., Dawson, J., Jorgensen, M., \& Macdougall, B. (2015). "Steering our own ship?" An assessment of self-determination and self-governance for community development in Nunavut. The Northern Review, 41, 157-180. https://doi.org/10.22584/nr41.2015.007

Rodon, T., \& Lévesque, F. (2015). Understanding the social and economic impacts of mining development in Inuit communities: Experiences with past and present mines in Inuit Nunangat. Northern Review, 41, 13-39. https://doi. org/10.22584/nr41.2015.002

Rogers, S. (2013, September 27). Inuit employment in Nunavik mines still weak. Retrieved from http://www.nunatsiaqonline.ca/stories/ article/65674inuit_employment_in_nunavik_mines_remains_weak/

Skura, E. (2016, October 12). Baffinland not meeting Inuit employment goals at Mary River: QIA. Retrieved from http://www.cbc.ca/news/canada/north/ baffinland-qia-mary-river-review-1.3800652

Taylor, A., \& Friedel, T. (2011). Enduring neo-liberalism in Alberta's oilsands: The troubling effects of private-public partnerships for First Nations and Metis communities. Citizenship Studies, 15(6-7), 815-835.

The Mary River Project Inuit Impact and Benefit Agreement. (2013). Retrieved from http://qia.ca/wp-content/uploads/2017/05/Complete_Mary_River_IIBA_ from_QIA.pdf

Nunavut Tunngavik Inc. (2004). Tukisittiarniqsaujumaviit? A plain language guide to the Nunavut Land Claims Agreement. Iqaluit, NU: Author. Retrieved from http://www.tunngavik.com/documents/publications/2004-00-00-A-PlainLanguage-Guide-to-the-Nunavut-Land-Claims-Agreement-English.pdf 